\title{
Mast Cells Are Dispensable in a Genetic Mouse Model of Chronic Dermatitis
}

\author{
Jitka Sulcova, ${ }^{*}$ Michael Meyer, ${ }^{*}$ Eva Guiducci, ${ }^{*}$ Thorsten B. Feyerabend ${ }^{\dagger}$ Hans-Reimer Rodewald ${ }^{\dagger}$ and Sabine Werner*
}

From the Department of Biology, ${ }^{*}$ Institute of Molecular Health Sciences, ETH Zurich, Zurich, Switzerland; and the German Cancer Research Center, ${ }^{\dagger}$ Heidelberg, Germany

\author{
Accepted for publication \\ February 12, 2015. \\ Address correspondence to \\ Sabine Werner, Ph.D., Institute \\ of Molecular Health Sciences, \\ ETH Zurich, Otto-Stern-Weg 7, \\ 8093 Zurich, Switzerland. \\ E-mail: sabine.werner@biol. \\ ethz.ch.
}

\begin{abstract}
Chronic inflammatory skin diseases, such as atopic dermatitis, affect a large percentage of the population, but the role of different immune cells in the pathogenesis of these disorders is largely unknown. Recently, we found that mice lacking fibroblast growth factor receptor 1 (Fgfr1) and Fgfr2 (K5-R1/R2 mice) in the epidermis have a severe impairment in the epidermal barrier, which leads to the development of a chronic inflammatory skin disease that shares many features with human atopic dermatitis. Using Fgfr1-/Fgfr2deficient mice, we analyzed the consequences of the loss of mast cells. Mast cells accumulated and degranulated in the skin of young Fgfr1-/Fgfr2-deficient mice, most likely as a consequence of increased expression of the mast cell chemokine $\mathrm{Ccl} 2$. The increase in mast cells occurred before the development of histological abnormalities, indicating a functional role of these cells in the inflammatory skin phenotype. To test this hypothesis, we mated the Fgfr1-/Fgfr2-deficient mice with mast cell-deficient CreMaster mice. Surprisingly, loss of mast cells did not or only mildly affect keratinocyte proliferation, epidermal thickness, epidermal barrier function, accumulation and activation of different immune cells, or expression of different proinflammatory cytokines in the skin. These results reveal that mast cells are dispensable for the development of chronic inflammation in response to a defect in the epidermal barrier. (Am J Pathol 2015, 185: 1575-1587; http://dx.doi.org/10.1016/j.ajpath.2015.02.005)
\end{abstract}

A large percentage of the population has the chronic inflammatory skin disease atopic dermatitis (AD). This disease affects adults and children with worldwide prevalence rates of $1 \%$ to $20 \%$, and the incidence has increased twofold to threefold during the last 40 years. ${ }^{1}$ External challenges, such as exposure to allergens, irritants, and pathogens and/ or genetic or epigenetic alterations in genes that are expressed in keratinocytes, can lead to skin damage, disruption of its barrier function, and subsequent development of AD. In particular, mutations that lead to a defect in the epidermal barrier strongly increase the risk of $\mathrm{AD}$ development. Thus, up to $15 \%$ of all patients and up to $50 \%$ of patients with severe disease have mutations in the gene encoding filaggrin, a structural protein of the epidermis. ${ }^{2-5}$ Furthermore, variants of the gene encoding SPINK5, a protease inhibitor involved in desquamation, are linked to $\mathrm{AD},{ }^{6-8}$ as well as mutations in genes encoding tight junction components (eg, claudin- 1 and claudin-23). ${ }^{9}$

Alterations in tight junction components may also result from defects in the transcriptional regulation of their genes.
Thus, we recently found that loss of fibroblast growth factor receptor 1 (Fgfr1) and Fgfr2 in keratinocytes in mice caused a severe defect in the epidermal barrier. This phenotype was at least in part the consequence of reduced expression of major tight junction components, which are up-regulated in keratinocytes of normal mice by dermally derived Fgfs, in particular Fgf7 and Fgf10. ${ }^{10}$ The down-regulation of tight junction proteins in the Fgfr mutant mice (designated K5$\mathrm{R} 1 / \mathrm{R} 2$ mice) caused functional deficits of these junctions, and the mice developed a phenotype, which shares various features with the abnormalities observed in flaky tail mice (mutations in the filaggrin and matted genes) $)^{11-13}$ and in patients with chronic AD (Table 1). Consistent with our findings, down-regulation of FGFR1 and FGFR2 expression

Supported by the ETH Zurich (S.W.), grant 310030_132884 from the Swiss National Science Foundation (S.W.), ERC Advanced grant 233074 from the European Research Council (H.R.R.), and a doctoral fellowship from the Ernst-Schering Foundation (J.S.).

Disclosures: None declared. 
Table 1 Comparison of Pathological Features in Patients With Atopic Dermatitis in Flaky Tail and K5-R1/R2 Mice

\begin{tabular}{|c|c|c|c|}
\hline Parameters & Atopic dermatitis patients & Flaky tail mice & K5-R1/R2 mice \\
\hline TEWL & $\uparrow^{16}$ & $\uparrow^{13,17}$ & $\uparrow^{10}$ \\
\hline Epidermal thickness & $\uparrow^{18-20}$ & $\uparrow^{11,17,21-23}$ & $\uparrow^{10}$ \\
\hline $\operatorname{IgE}$ and $\operatorname{IgG}$ & $\uparrow^{20,24,25}$ & $\uparrow^{13,17,22}$ & $\uparrow^{10}$ \\
\hline Epidermal $\gamma \delta$ T cells & Not reported & Not reported & $\uparrow^{10}$ \\
\hline Epidermal $\alpha \beta$ T cells & Not reported & Not reported & $\uparrow$ This study \\
\hline Langerhans cells & $\uparrow^{26}$ & $\uparrow^{27}$ & $\uparrow$ This study \\
\hline Eosinophils & $\uparrow^{18,24}$ & $\uparrow^{11,23}$ & No difference (data not shown) \\
\hline Dermal T cells & $\uparrow^{31,32}$ & $\uparrow^{11,13,22,23}$ & $\uparrow^{10}$ \\
\hline Mast cells & $\uparrow^{33,34}$ & $\uparrow^{17}$ & $\uparrow^{10}$ \\
\hline
\end{tabular}

Flaky tail mice, which have mutations in the filaggrin and matted genes, ${ }^{12}$ were included in the comparison because they represent an established mouse model for atopic dermatitis. ${ }^{11}$ Parameters analyzed include transepidermal water loss, epidermal thickening, serum levels of IgE and IgG, and number of epidermal $\gamma \delta$ T cells, $\alpha \beta$ T cells, Langerhans cells, dermal neutrophils, eosinophils, T cells, and mast cells. Arrow indicates an increase in a particular parameter.

was detected in the skin of $\mathrm{AD}$ patients, ${ }^{14}$ and singlenucleotide polymorphisms in the FGFR1 and FGFR2 genes were linked to atopy. ${ }^{15}$ Therefore, K5-R1/R2 mice are useful to study the molecular and cellular mechanisms underlying chronic skin inflammation that results from a defective barrier.

Because most studies found increased numbers of mast cells in skin lesions of patients with $\mathrm{AD}$, it is generally assumed that mast cells contribute to the development and/or maintenance of skin inflammation in these patients. ${ }^{33,34}$ Mast cells are particularly abundant at the host's interface with the environment, such as the skin or mucosae. They are longlived cells, which proliferate in response to appropriate stimuli. $^{35}$ They express a high-affinity FceRI receptor that strongly binds $\operatorname{IgE}$ antibodies. Interestingly, the latter are abundant in the skin and the serum of K5-R1/R2 mice and of $\mathrm{AD}$ patients (Table 1). On binding of allergens to mast cell-bound IgE, degranulation of mast cells occurs, resulting in release of bioactive molecules stored in granules, including histamine, heparin, different proteases, and proinflammatory cytokines. This causes vessel dilatation, local edema, activation of other immune cells, and inflammation. ${ }^{36}$

Previous studies ${ }^{37-41}$ using different mouse models have addressed the potential role of mast cells in AD. The allergeninduced skin inflammation that results from epicutaneous application of ovalbumin to mice and that elicits some characteristics of $\mathrm{AD}$ was not affected in mast cell-deficient $\mathrm{Kit}^{W / W-v}$ mice. ${ }^{37}$ Consistent with this finding, the AD-like symptoms were only mildly reduced in FceRI-deficient mice. ${ }^{38}$ On the other hand, skin inflammation induced by epicutaneous sensitization with cedar pollen antigens was abolished in $K i t^{W / W-v}$ and $K i t^{S / S l-d}$ mice. ${ }^{39}$ Similarly, the AD-like symptoms induced by epicutaneous application of Dermatophagoides farinae extract and staphylococcal enterotoxin B were strongly reduced in $\mathrm{Kit}^{\mathrm{W-sh} / \mathrm{W} \text {-sh } 40}$ and also in Cpa3-Cre transgenic, $\mathrm{Mcl}-1^{f l f l}$ mice, ${ }^{41}$ which lack mast cells and basophils and have macrocytic anemia and neutrophilia. ${ }^{42}$ These findings suggest that mast cells are dispensable for cutaneous inflammation induced by epicutaneous ovalbumin sensitization but not in Dermatophagoides farinae extract-, staphylococcal enterotoxin $\mathrm{B}-$, or cedar pollen-induced dermatitis, which induce stronger AD-like symptoms. However, $\mathrm{Kit}^{W / W-v}$ or $\mathrm{Kit}^{\mathrm{W-sh} / \mathrm{W}-\mathrm{sh}}$ mice should be considered to have various other hematopoietic and nonhematopoietic abnormalities, ${ }^{43,44}$ which may affect the result and complicate the interpretation.

Because the role of mast cells in a genetic model of chronic dermatitis with impaired barrier function has not been studied yet, we analyzed the consequences of the loss of mast cells in K5-R1/R2 mice. We mated K5-R1/R2 mice with CreMaster mice, which express Cre recombinase under the control of the endogenous Cpa3 locus. This leads to efficient depletion of mast cells during their development due to the genotoxicity of Cre. Therefore, CreMaster mice are constitutively devoid of mast cells, and they do not reappear during postnatal development. ${ }^{45}$ Importantly, these mice do not have additional immunological abnormalities or other pathological features, except a reduction in the number of basophils. Therefore, analysis of the progeny of this breeding allowed us to determine the function of mast cells in a genetic mouse model that exhibits important features of AD. We report that mast cells are dispensable in this genetic mouse model of chronic dermatitis despite their early increase and strong degranulation in the skin.

\section{Materials and Methods}

\section{Mice}

Mice with floxed $F g f r l$ and floxed $F g f r 2$ alleles were mated with transgenic mice expressing Cre recombinase under the control of the keratin 5 (K5) promoter. The progeny were designated K5-R1/R2 mice and described previously. ${ }^{10}$ K5-R1/R2 mice were further bred to mast cell-deficient CreMaster mice ${ }^{45}$ to obtain quadruple mutant mice (designated K5-R1/R2-CreMaster). Because of the difficult breeding scheme, each experiment included mice from different litters, but at least one to two controls; CreMaster, 
Table 2 Real-Time PCR Primers

\begin{tabular}{|c|c|c|}
\hline Target gene & Forward sequence & Reverse sequence \\
\hline Scf & 5'-САТTTATCTTCAАСTGCTCCTATTT-3' & 5'-GGTCATCCACTATTTTCCCAAG-3' \\
\hline Ccl6 & 5'-TTCTGGGCCTGCTGTTCAC-3' & $5^{\prime}$-GAGCCAACACGTGGATGCT-3' \\
\hline Ccl2 & 5'-ATCAAGCCGGGCATCATCTTTA-3' & $5^{\prime}-\mathrm{TGCCCTCCTTCTCAAGCAAT-3^{ \prime }}$ \\
\hline Claudin3 & 5'-GCGGCTCTGCTCACCTTAGT-3' & 5'-GACGTAGTCCTTGCGGTCGTA-3' \\
\hline Il1f8 & 5'-GCCTGTCATTCTTAGCTTGAT-3' & 5'-TGTCTACTTCCTTAAGCTGC-3' \\
\hline Tnfa & 5'-TGGCCCAGGCAGTCAGA-3' & 5'-GTTTGCTACAACATGGGCTACA-3' \\
\hline Tgfb1 & $5^{\prime}$-AGCCCGAAGCGGACTACTAT- $3^{\prime}$ & $5^{\prime}$-TCCACATGTTGCTCCACACT-3' \\
\hline Ifng & 5'-TTTTAACTCAAGTGGCATAGATGTG-3' & 5'-ATGAATGCATCCTTTTTCGC-3' \\
\hline Il5 & $5^{\prime}-$ ACATTGACCGCCAAAAAGAG- $3^{\prime}$ & $5^{\prime}$-ATCCAGGAACTGCCTCGTC-3' \\
\hline Il10 & 5'-TGCTATGCTGCCTGCTCTTA-3' & 5'-ATGTTGTCCAGCTGGTCCTT-3' \\
\hline Il12 & $5^{\prime}$-CCATCAGCAGATCATTCTAGACAA-3' & 5'-CGCCATTATGATTCAGAGACTG-3' \\
\hline Rps29 & $5^{\prime}$-GGTCACCAGCAGCTCTACTG-3' & 5'-GTCCAACTTAATGAAGCCTATGTCC-3' \\
\hline
\end{tabular}

K5-R1/R2, and K5-R1/R2-CreMaster littermates were used for a direct comparison in all experiments. All mice had a C57BL/6 genetic background. They were housed under optimal hygiene conditions and received food and water ad libitum. Mouse maintenance and all animal experiments had been approved by the veterinary authorities of Zurich, Switzerland.

\section{Histologic Analysis}

Skin biopsy specimens were fixed overnight with 95\% ethanol/1\% acetic acid followed by paraffin embedding. Sections $(7 \mu \mathrm{m})$ were stained with hematoxylin and eosin or with toluidine blue to detect mast cells and their degranulation as described previously. ${ }^{10}$ Sections were analyzed with an Axioskop 2 microscope equipped with a Plan-Neofluar objective $(20 \times / 0.5 \mathrm{NA})$ and photographed with an Axiocam HRc camera (all from Carl Zeiss Inc., Jena, Germany). Axiovision software version 4.6 (Carl Zeiss, Inc.) was used for data acquisition. Data analysis was performed using ImageJ version 1.48 (NIH, Bethesda, MD). All analyses were performed blinded to the genotype of the mice (J.S.).

\section{BrdU Incorporation Studies}

Mice were injected intraperitoneally with 5-bromo-2'deoxyuridine (BrdU) $(250 \mathrm{mg} / \mathrm{kg}$ in $0.9 \% \mathrm{NaCl}$; Sigma, Munich, Germany) and sacrificed 2 hours after injection. Skin biopsy specimens were fixed overnight with $95 \%$ ethanol $/ 1 \%$ acetic acid followed by paraffin embedding. Sections were deparaffinized, washed in $100 \%$ ethanol for 5 minutes at room temperature, and fixed with $100 \%$ methanol for 10 minutes at $4^{\circ} \mathrm{C}$. They were denatured in $2 \mathrm{~N} \mathrm{HCl}$ for 30 minutes at $37^{\circ} \mathrm{C}$, followed by neutralization with $0.1 \mathrm{~mol} / \mathrm{L}$ borate buffer $(\mathrm{pH} 8.5)$ for 30 minutes at room temperature. After washing, sections were blocked with

phosphate-buffered saline containing $3 \%$ bovine serum albumin and $0.025 \% \mathrm{NP}-40$ for 30 minutes at $37^{\circ} \mathrm{C}$. Primary BrdU fluorescein isothiocyanate antibody (Roche, Rotkreuz, Switzerland) and $2 \mu \mathrm{g} / \mathrm{mL}$ propidium iodide as a counterstain were applied for 4 hours at room temperature in the same buffer. After washing, slides were mounted with

Table 3 Antibodies Used for Flow Cytometry Analysis

\begin{tabular}{lllll}
\hline Antigen & Clone & Fluorophor & Dilution & Source \\
\hline CD32 & $2.4 G 2$ & & $1: 200$ & BD Biosciences \\
CD45 & 30-F11 & APC & $1: 800$ & BD Biosciences \\
CD3 & 145-2C11 & PE-CF594/PE & $1: 300 / 400$ & BD Biosciences \\
CD4 & GK1.5 & PE & $1: 800$ & BD Biosciences \\
CD8 & $53-6.7$ & PE & $1: 800$ & BD Biosciences \\
CD5 & $53-7.3$ & PE & $1: 400$ & BD Biosciences \\
TER119 & TER-119 & PE & $1: 400$ & BD Biosciences \\
NK1.1 & PK136 & PE & $1: 400$ & BD Biosciences \\
CD19 & eBio1D3 & PE & $1: 400$ & BD Biosciences \\
Gr-1 & RB6-8C5 & PE & $1: 800$ & BD Biosciences \\
TCR 3 & H57-597 & PE-Cy7 & $1: 500$ & BD Biosciences \\
TCR8 & GL3 & FITC & $1: 400$ & BD Biosciences \\
CD11C & HL3 & PE-Cy7/PE & $1: 400 / 600$ & BD Biosciences \\
Ly6G & 1A8 & FITC & $1: 400$ & BD Biosciences \\
Integrin $\beta 7$ & M293 & FITC & $1: 300$ & BD Biosciences \\
I-A/I-E & $2 G 9$ & PE & $1: 4000$ & BD Biosciences \\
CD11b & M1/70 & BV711/PE & $1: 500 / 2000$ & Biolegend \\
F4/80 & BM8 & BV421 & $1: 200$ & Biolegend \\
CD117 & 2B8 & APC-Cy7 & $1: 400$ & Biolegend \\
Sca-1 & E13-161-7 & PE-Cy7 & $1: 500$ & Biolegend \\
CD69 & H1.2F3 & BV421 & $1: 200$ & Biolegend \\
FcERI $\alpha$ & MAR-1 & PE & $1: 200$ & eBioscience \\
CD27 & LG.7F9 & APC & $1: 400$ & eBioscience \\
CD86 & GL1 & FITC & $1: 400$ & eBioscience \\
T1/ST2 & DJ8 & Biotin & $1: 600$ & MD Bioscience \\
\hline APC, allophycocyanin; FITC, & fluorescein & isothiocyanate; PE, \\
phycoerythrin. & & & & \\
& & & & \\
\hline
\end{tabular}



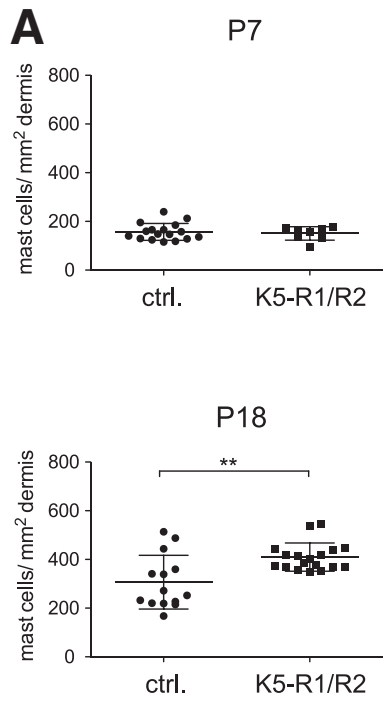

B
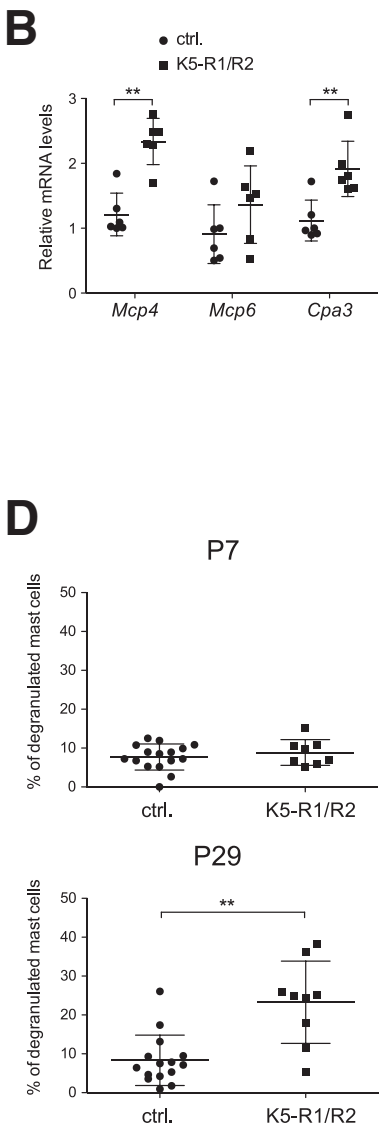

E

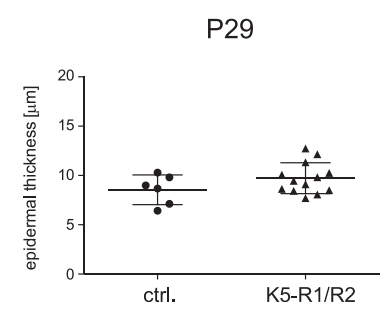

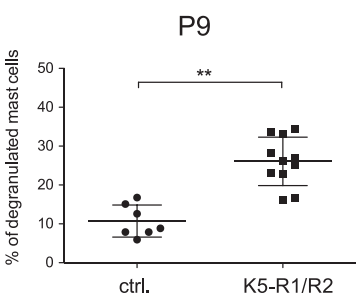
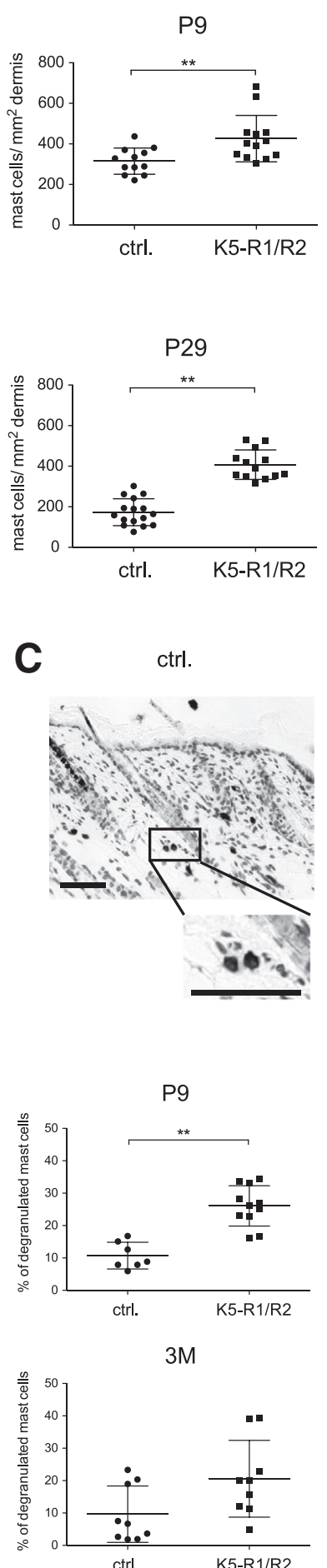

C

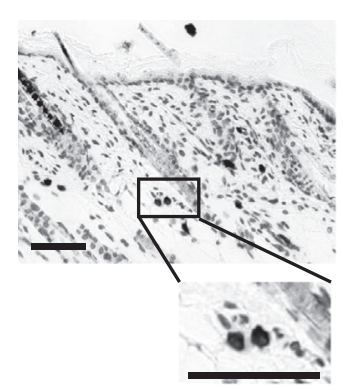

ctrl.
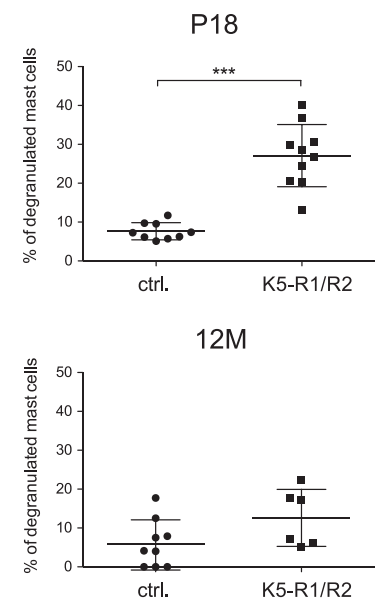

Figure 1 Early accumulation and activation of dermal mast cells in K5-R1/R2 mice. A: Number of mast cells as determined by toluidine blue staining of paraffin sections from back skin of K5-R1/R2 mice and control (ctrl) littermates on postnatal day 7 (P7), P9, P12, $P 18$, and P29. At least $5 \mathrm{~mm}$ of the skin was analyzed per mouse. B: RNA from total back skin of mice on P9 was analyzed by quantitative real-time RT-PCR for the expression of Mcp4, Mcp6, and Cpa3. Rps29 mRNA was used for normalization. C: Representative image of toluidine blue-stained paraffin sections from back skin at P9 shows enhanced mast cell degranulation in K5-R1/R2 mice. D: The percentage of degranulated mast cells among all mast cells was determined by light microscopy analysis of toluidine blue-stained paraffin sections from back skin. At least $5 \mathrm{~mm}$ of the skin was analyzed per mouse. E: Epidermal thickness determined in hematoxylin and eosin-stained skin sections and keratinocyte proliferation in the epidermis as determined by 5-bromo-2'-deoxyuridine staining of paraffin sections from back skin at P29 and the age of 2 months (2M). At least $5 \mathrm{~mm}$ of the skin was analyzed per mouse. Data are representative of two experiments and are expressed as means \pm SD. $n=17 \mathrm{ctrl}$ and 8 K5-R1/R2 mice for P7; $n=12 \mathrm{ctrl}$ and $13 \mathrm{~K} 5$ R1/R2 mice for P9; $n=18$ ctrl and $10 \mathrm{~K} 5-\mathrm{R} 1 /$ R2 mice for P12; $n=14 \mathrm{ctrl}$ and $18 \mathrm{~K} 5-\mathrm{R} 1 / \mathrm{R} 2$ mice for $\mathrm{P} 18 ; n=16 \mathrm{ctrl}$ and $13 \mathrm{~K} 5-\mathrm{R} 1 / \mathrm{R} 2$ mice for P29 (A). $n=6$ ctrl, 6 K5-R1/R2 mice (B). $n=17 \mathrm{ctrl}$ and $8 \mathrm{~K} 5-\mathrm{R} 1 / \mathrm{R} 2$ mice for P7; $n=7 \mathrm{ctrl}$ and $11 \mathrm{~K} 5-\mathrm{R} 1 / \mathrm{R} 2$ mice for P9; $n=9 \mathrm{ctrl}$ and $10 \mathrm{~K} 5-\mathrm{R} 1 / \mathrm{R} 2$ mice for P18; $n=15 \mathrm{ctrl}$ and $9 \mathrm{~K} 5-\mathrm{R} 1 / \mathrm{R} 2$ mice for P29; $n=9 \mathrm{ctrl}$ and $9 \mathrm{~K} 5-\mathrm{R} 1 / \mathrm{R} 2$ mice for 3 months; $n=9$ ctrl and 6 K5-R1/R2 mice for 12 months (D). $n=6$ ctrl and 13 K5-R1/R2 mice for P29; $n=14 \mathrm{ctrl}$ and $9 \mathrm{~K} 5-\mathrm{R} 1 / \mathrm{R} 2$ mice for 2 months (E). ${ }^{* *} P \leq 0.01,{ }^{* * *} P \leq 0.001$. Scale bar $=$ $50 \mu \mathrm{m}$ (the area indicated by the rectangle is shown at higher magnification) (C). 
Mowiol (Sigma). Sections were photographed using an Imager.A1 microscope equipped with an enhanced-contrast Plan-Neofluar objective $(20 \times / 0.5 \mathrm{NA})$ and photographed with an Axiocam MRm camera (all from Carl Zeiss Inc.). Axiovision software version 4.6 (Carl Zeiss Inc) was used for data acquisition. Data analysis was performed using ImageJ version 1.48 .

\section{TEWL}

Mouse back skin was shaved 1 day before analysis. Transepidermal water loss (TEWL) was determined using a Tewameter (Courage and Khazaka Electronic GmbH, Cologne, Germany). The probe measures the density gradient of the water evaporation from the skin indirectly by two pairs of sensors: temperature and relative humidity. A microprocessor analyzes the values and expresses the evaporation rate in grams per hour per square meter. The Tewa probe was placed on the dorsal skin, and 20 consecutive measurements were taken from four different places on the back, in total 80 measurements per mouse.

\section{Isolation of RNA from Mouse Skin}

Mice were sacrificed and shaved, and epidermis from the back skin was separated from the dermis after heat shock treatment ( 30 seconds at $60^{\circ} \mathrm{C}$ followed by 1 minute at $4^{\circ} \mathrm{C}$ ). Isolated epidermis and dermis were immediately frozen in liquid nitrogen. RNA isolation using TRIzol was performed as described previously. ${ }^{46}$

\section{Real-Time RT-PCR}

Quantitative real-time RT-PCR (RT-qPCR) was performed according to the manual of the Light Cycler 480 II (Roche). The RT product obtained from $12.5 \mathrm{ng}$ of RNA was used together with $6 \mu \mathrm{L}$ of SYBR Green reaction mix, including $0.45 \mu \mathrm{mol} / \mathrm{L}$ forward and reverse primer mix. The reaction was performed in 50 cycles $\left(95^{\circ} \mathrm{C}\right.$ for 10 minutes for initial denaturation; $95^{\circ} \mathrm{C}$ for 10 seconds, $60^{\circ} \mathrm{C}$ for 20 seconds, and $72^{\circ} \mathrm{C}$ for 20 seconds for each cycle). Samples were analyzed in duplicates. The primers are listed in Table 2.

\section{Isolation of Cells from Bone Marrow, Subcutaneous Adipose Tissue, and Skin}

Mice were sacrificed and shaved, and the back skin and the bone marrow were harvested. Bone marrow cells were flushed from the femurs and tibias with RPMI 1640 medium supplemented with penicillin/streptomycin and $20 \mathrm{mmol} / \mathrm{L}$ HEPES. Erythrocytes were lyzed with BD Pharm Lyse (BD Biosciences, San Jose, CA), and the remaining nucleated bone marrow cells were washed with $1 \times$ phosphate-buffered saline.

The subcutaneous fat was scraped off and treated with $0.25 \mathrm{mg} / \mathrm{mL}$ TL Liberase (Roche) in RPMI 1640 medium supplemented with penicillin/streptomycin and $20 \mathrm{mmol} / \mathrm{L}$

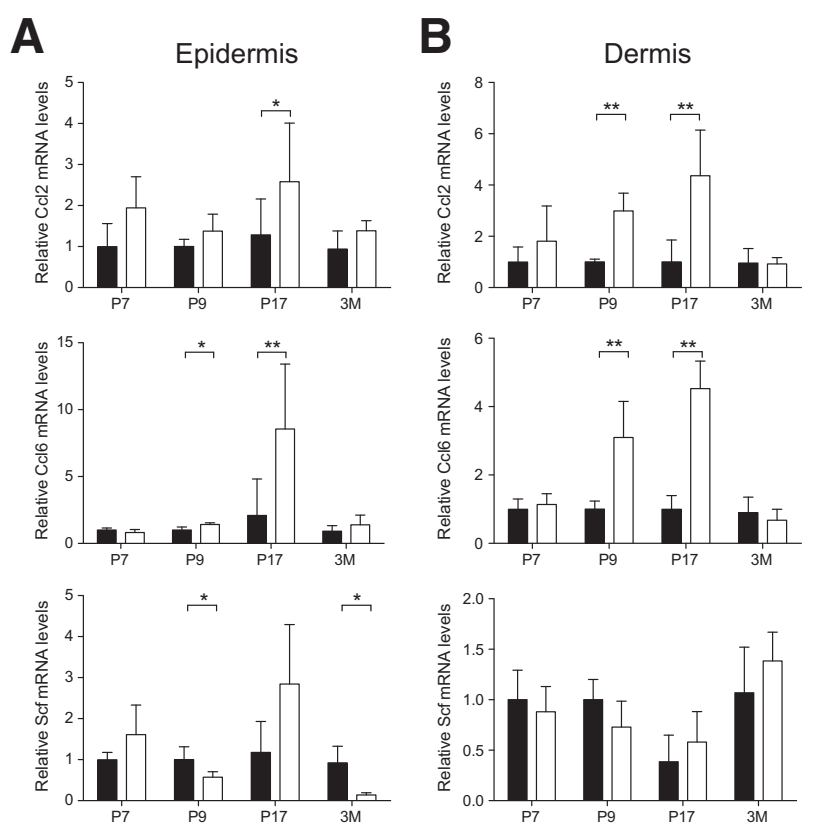

Figure 2 Transient increase in mast cell chemokines and mitogens in the skin of K5-R1/R2 mice. RNA from the epidermis (A) or dermis (B) of postnatal day 7 (P7), P9, P17, and 3-month-old (3M) mice was analyzed by quantitative real-time RT-PCR for the expression of $\mathrm{Ccl} 2, \mathrm{Ccl} 6$, and stem cell factor. Rps29 mRNA was used for normalization. Data are representative of two experiments and are expressed as means \pm SD. $n=4$ control, 7 K5-R1/ R2 mice for P7, $n=6$ control, 6 K5-R1/R2 mice for P9, $n=5$ control, 6 K5-R1/R2 mice for P17, and $n=6$ control, 6 K5-R1/R2 mice for 3 months. ${ }^{*} P \leq 0.05,{ }^{*} P \leq 0.01$.

HEPES for 1.5 hours at $37^{\circ} \mathrm{C}$ under continuous shaking. Epidermis and dermis were separated using $0.25 \%$ dispase (Gibco, Zug, Switzerland) for 50 minutes at $37^{\circ} \mathrm{C}$ under continuous shaking. The epidermis was treated with 100 Kunitz units/mL DNase (Sigma) in RPMI 1640 medium supplemented with penicillin/streptomycin, $10 \%$ fetal bovine serum, and $20 \mathrm{mmol} / \mathrm{L}$ HEPES for 45 minutes at $37^{\circ} \mathrm{C}$ under continuous shaking. The dermis was cut into small pieces and treated with $0.25 \mathrm{mg} / \mathrm{mL}$ TL Liberase in RPMI 1640 medium supplemented with penicillin/streptomycin and $20 \mathrm{mmol} / \mathrm{L}$ HEPES for 1 hour at $37^{\circ} \mathrm{C}$ under continuous shaking. Single-cell suspensions were prepared by passing mixtures through $70-\mu \mathrm{m}$ cell strainers, and cells were washed with $1 \times$ phosphate-buffered saline.

\section{Flow Cytometry}

Unspecific binding sites were blocked with anti-CD16/ CD32 antibody. Dead cells were stained with Zombie Aqua dye (BioLegend, San Diego, CA). Antibodies used for flow cytometry analysis are listed in Table 3. Stained cells were analyzed using BD Fortessa and BD FACSDiva software version 6.0 (both from BD Biosciences). Data analysis was performed using FlowJo software version 10 (FlowJo, Ashland, OR). Compensation was performed using single-color controls prepared from the mixture of 
skin and spleen (skin analysis) or bone marrow (bone marrow analysis). Compensation matrices were calculated using BD FACSDiva software version 6.0 (BD Biosciences) and applied. Doublets and dead cells were excluded from the analysis. Fluorescence minus one controls were used for gating analyses to distinguish positively from negatively staining cell populations. This control contains all fluorochromes in a panel, with the exception of the one that is being measured.

\section{Statistical Analysis}

Statistical analysis was performed using PRISM software version 5 (Graph Pad Software Inc., La Jolla, CA). Mann-Whitney $U$ test was used for comparison between two different groups. Error bars represent SD in all graphs.

\section{Results}

Early Accumulation and Activation of Dermal Mast Cells in $\mathrm{K} 5-\mathrm{R} 1 / \mathrm{R} 2$ Mice

To characterize the role of mast cells in the phenotype of K5-R1/R2 mice, we first determined the kinetics of postnatal mast cell accumulation in the back skin. Toluidine staining of skin sections revealed a similar number of mast cells in K5-R1/R2 and control mice at postnatal day 7 (P7). An increase in mast cell number occurred between P7 and $\mathrm{P} 9$ in control mice and even more in K5-R1/R2 mice.
A

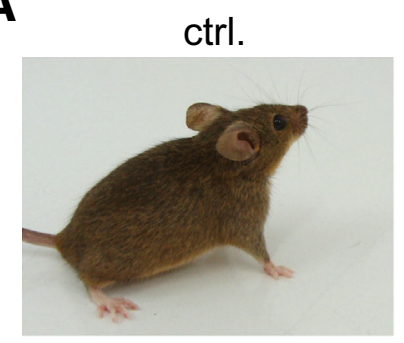

B

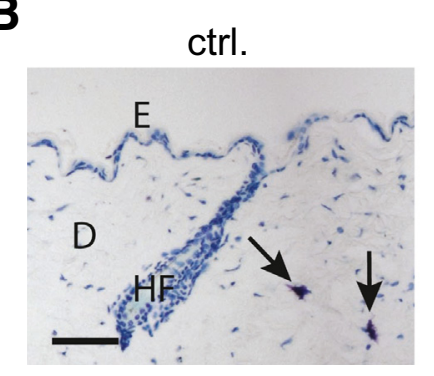

CreMaster

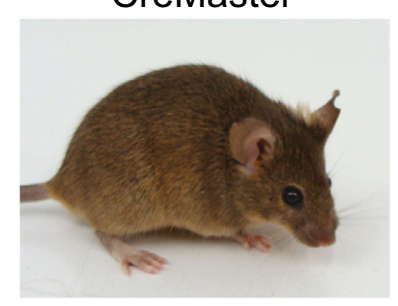

CreMaster

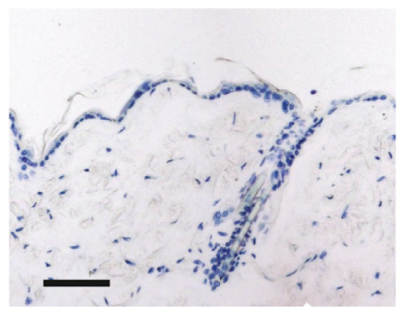

C

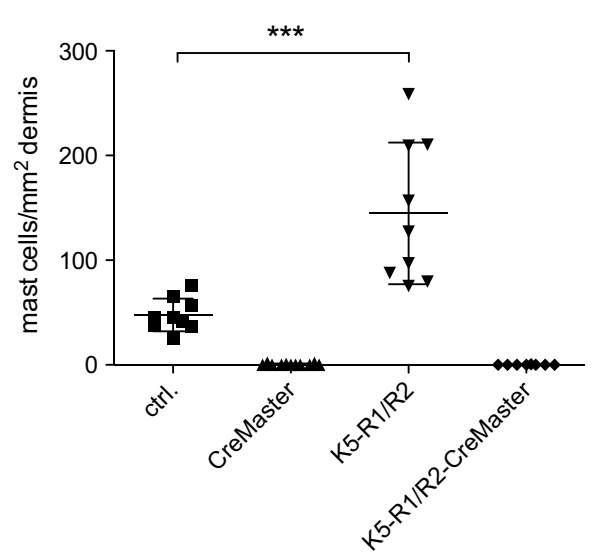

$\mathrm{K} 5-\mathrm{R} 1 / \mathrm{R} 2$

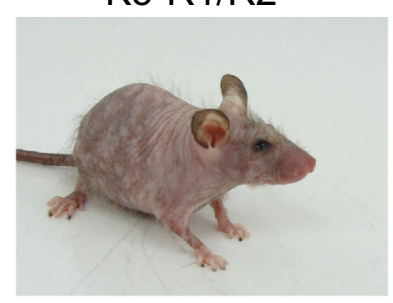

K5-R1/R2

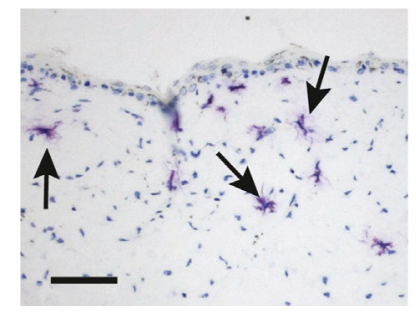

D

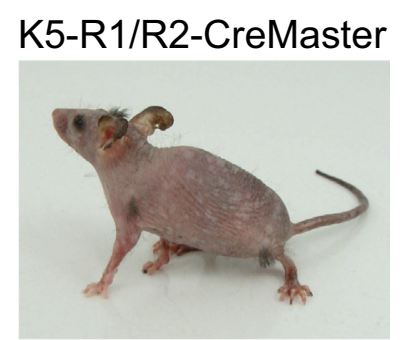

K5-R1/R2-CreMaster

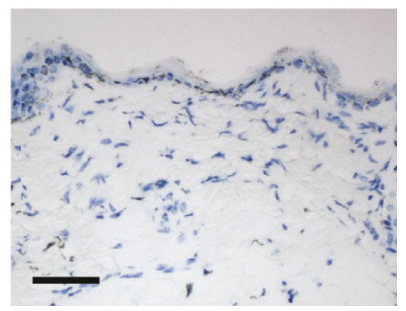

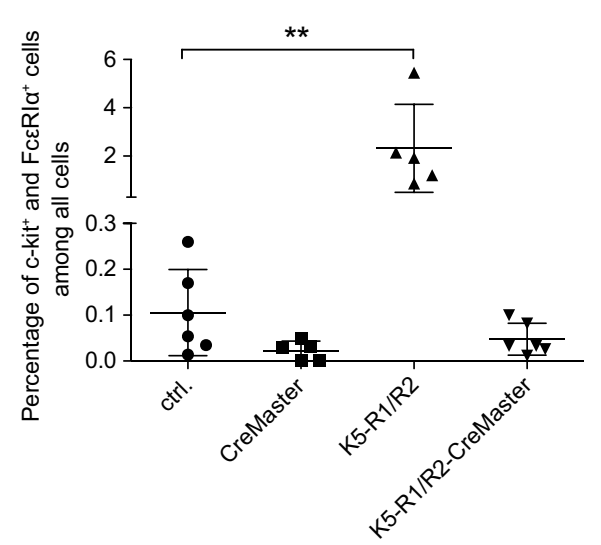

Figure 3 Mast cell deficiency does not affect the macroscopic phenotype of K5-R1/R2 mice. A: Representative images of 12-month-old mice from each genotype. B and C: Mast cells were identified by toluidine blue staining of paraffin sections from back skin (arrows) of 3-month-old mice and quantified. At least $5 \mathrm{~mm}$ of the skin was analyzed per mouse. D: Flow cytometry analysis of dermal cells from 3-month-old mice using c-Kit and FceRI $\alpha$ antibodies to detect mast cells. The percentage of mast cells among all cells is shown. Data are representative of two experiments and are expressed as means \pm SD (C and D). $n=6$ control (ctrl), 5 CreMaster, 5 K5-R1/R2, and 6 K5-R1/R2-CreMaster mice (D). $n=9$ ctrl, 11 CreMaster, 9 K5-R1/R2, and 8 K5-R1/ R2-CreMaster mice (note the lack of mast cells in all mice with CreMaster genotype) (B and $\mathbf{C})$. ${ }^{* * P} \leq 0.01,{ }^{* *} P \leq 0.001$. Scale bar $=50 \mu \mathrm{m}(\mathbf{B})$. $\mathbf{D}$, dermis; $\mathrm{E}$, epidermis; $\mathrm{HF}$, hair follicle. 
Although the number of mast cells remained high in K5-R1/ $\mathrm{R} 2$ mice, it decreased over time in control mice (Figure 1A). Concomitant with the increase in mast cell number in K5$\mathrm{R} 1 / \mathrm{R} 2$ mice, we observed an increase in the mRNA levels of Mcp4, Mcp6, and Cpa3 (Figure 1B). In young K5-R1/R2 mice, most of the mast cells were degranulated (Figure 1, C and $\mathrm{D}$ ), followed by a decrease in degranulated mast cells thereafter (Figure 1D). The appearance of mast cells in the skin and their degranulation preceded the onset of histopathological abnormalities in K5-R1/R2 mice, in particular the epidermal thickening and keratinocyte hyperproliferation, which progressed over time (Figure 1E). These findings raised the possibility of a causative role of mast cells in the development of the skin phenotype in K5$\mathrm{R} 1 / \mathrm{R} 2$ mice.
Transient Increase in Mast Cell Chemokines in the Skin of K5-R1/R2 Mice

To determine the reason for the accumulation of mast cells in the skin of K5-R1/R2 mice, we analyzed the expression of mast cell chemokines. Expression of $\mathrm{Ccl} 2$, a major mast cell progenitor attractant, ${ }^{47}$ and of Ccl6, an upstream regulator of $\mathrm{Ccl} 2,{ }^{48}$ was significantly higher in the epidermis and even more in the dermis of K5-R1/R2 mice compared with littermate controls (Figure 2, A and B). The increase in the epidermis is not a cell autonomous effect because these chemokines were expressed at similar levels in primary keratinocytes from control and K5-R1/R2 mice (data not shown). Highest expression levels of $\mathrm{Ccl} 2$ and $\mathrm{Ccl} 6$ correlated with the peak in mast cell number, and their expression
A

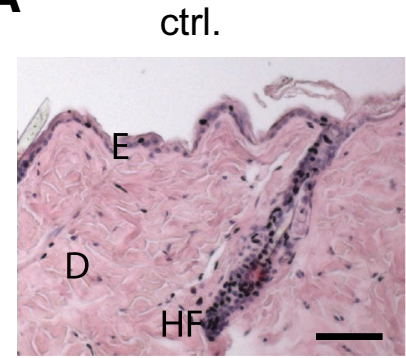

B

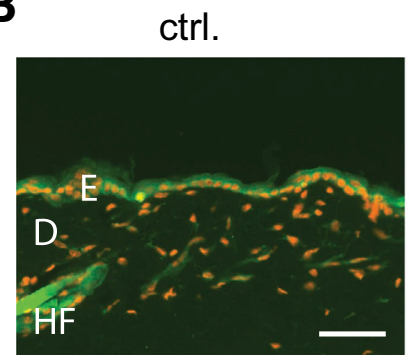

C

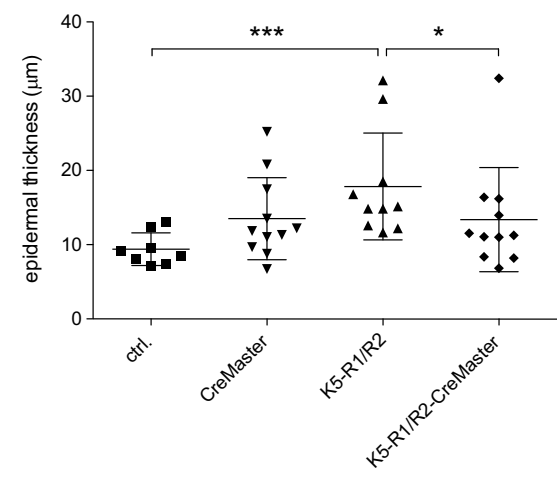

$\mathrm{K} 5-\mathrm{R} 1 / \mathrm{R} 2$

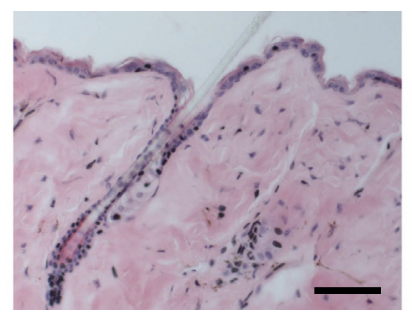

CreMaster
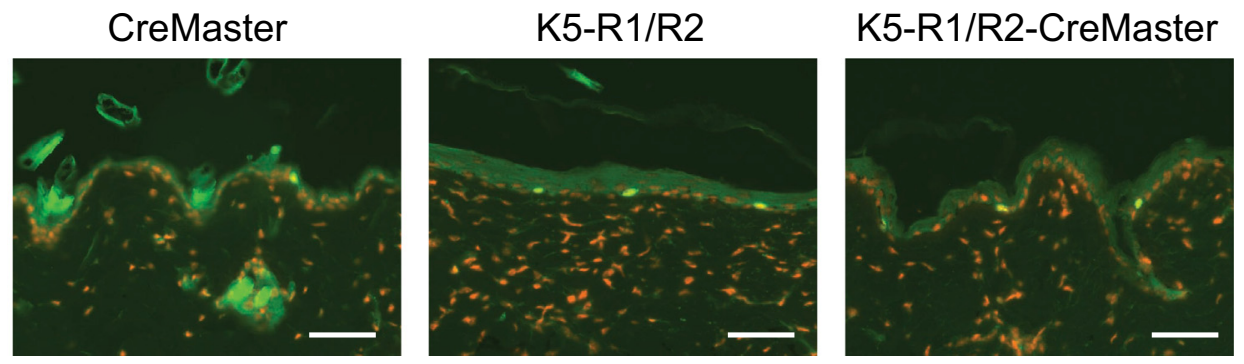

D

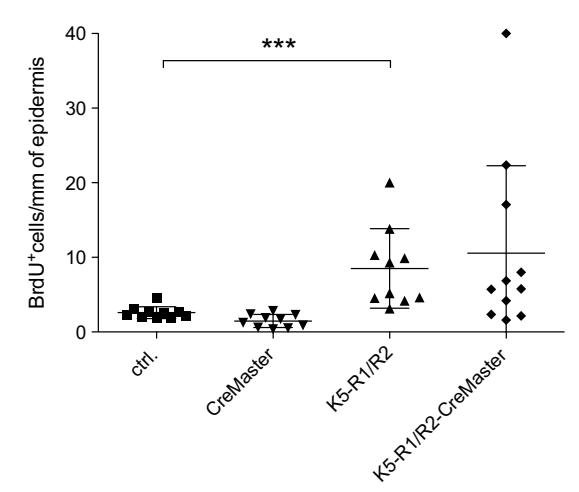

Figure 4 Loss of mast cells does not affect the loss of skin appendages, epidermal thickness, and keratinocyte proliferation in K5-R1/R2 mice. A: Representative photographs of hematoxylin and eosin (H\&E)-stained sections from back skin of 3-month-old mice. B: Representative images of back skin sections from 3-month-old mice stained with a 5-bromo-2'-deoxyuridine (BrdU) antibody (green) and counterstained with propidium iodide (red). C: Epidermal thickness was determined on H\&E-stained paraffin sections from back skin of 3-month-old mice. D: Quantification of BrdU-positive cells in the epidermis of 3-month-old mice. Data are expressed as means \pm SD (C and D). $n=8$ control (ctrl), 11 CreMaster, 10 K5-R1/R2, and 11 K5-R1/R2-CreMaster mice (C). $n=10 \mathrm{ctrl}, 10$ CreMaster, $10 \mathrm{~K} 5-\mathrm{R} 1 / \mathrm{R} 2$, and $11 \mathrm{~K} 5$-R1/R2-CreMaster mice for 3-month-old mice (D). ${ }^{*} P \leq 0.05,{ }^{* *} P \leq 0.001$. Scale bar $=50 \mu \mathrm{m}$ (A and B). D, dermis; E, epidermis; HF, hair follicle. 
subsequently decreased. Expression levels of other mast cell chemokines, including Ccl5, Cxc19, Cxcl10, and nerve growth factor were similar in mice of both genotypes (data not shown). Finally, mRNA levels of stem cell factor, a major mast cell growth factor and chemokine, which is increased in the serum of patients with $\mathrm{AD},{ }^{49}$ were even reduced in the epidermis of K5-R1/R2 mice and not affected in the dermis. These findings suggest that a transient increase in $\mathrm{Ccl} 6$ and $\mathrm{Ccl} 2$ could be responsible for the early increase in mast cells in the skin of K5-R1/R2 mice.

The increase in mast cell number may result from proliferation of skin-resident mast cells or from recruitment and local proliferation of bone marrow-derived mast cell progenitors (MCPs) as previously reported for inflamed skin. ${ }^{50}$ In addition, recruitment from the white adipose tissue may occur because white adipose tissue can serve as a source of MCPs. ${ }^{51}$ Consistent with this possibility, we found a significantly higher number of MCPs in the white adipose tissue of K5-R1/R2 mice compared with control mice (Supplemental Figure S1).

\section{Mast Cell Deficiency Does Not Affect the Macroscopic Phenotype of K5-R1/R2 Mice}

To investigate the role of mast cells in the AD-like phenotype of K5-R1/R2 mice, they were mated with mast cell-deficient CreMaster mice. ${ }^{45}$ The progeny was designated K5-R1/R2-CreMaster.

K5-R1/R2-CreMaster mice were macroscopically similar to K5-R1/R2 mice at P17, the age of 3 months (data not shown), and the age of 12 months (Figure $3 \mathrm{~A}$ ). In agreement with the phenotype of K5-R1/R2 mice, both strains were viable, all females and most males were sterile, mice of both sex lost hair, and they had a lower body weight compared with control and CreMaster mice (Figure 3A) (data not shown). Mast cell deficiency in K5-R1/R2-CreMaster and CreMaster mice was verified by toluidine blue staining of skin sections (Figure 3, B and C) and by flow cytometry (Figure 3D) at the age of 3 months. The very weak signal that we obtained with samples from CreMaster and K5-R1/R2-CreMaster mice reflects flow cytometry staining background. Mast cells also did not reappear on aging as determined by toluidine blue staining of skin sections of 12-month-old mice (Supplemental Figure S2). Therefore, the macroscopic abnormalities observed in K5-R1/R2 mice are independent of the presence of mast cells.

\section{Loss of Mast Cells Does Not Affect Acanthosis and Keratinocyte Hyperproliferation in K5-R1/R2 Mice}

Because the skin of K5-R1/R2 mice and lesional skin of $\mathrm{AD}$ patients are characterized by a strong increase in epidermal thickness (acanthosis), ${ }^{18-20}$ we investigated the role of mast cells in the acanthosis of K5-R1/R2 mice. Epidermal thickness was significantly increased in
$\mathrm{K} 5-\mathrm{R} 1 / \mathrm{R} 2$ mice compared with controls, and there was a small decrease in the absence of mast cells at the age of 3 months (Figure 4, A and C). This was, however, no longer observed at the age of 12 months (Supplemental Figure S3, A and C). In agreement with the similar severity of the acanthosis, we did not observe obvious differences in the proliferation rate of epidermal keratinocytes between K5-R1/R2 and K5-R1/R2-CreMaster mice at the age of 3 months (Figure 4, B and D) and 12 months (Supplemental Figure S3, B and D). Therefore, the acanthosis and keratinocyte hyperproliferation that occur in the absence of Fgfr1 and Fgfr2 in keratinocytes are independent of the presence of mast cells.

\section{Loss of Mast Cells Does Not Influence the Epidermal Barrier Defect in K5-R1/R2 Mice}

One of the early and major symptoms of K5-R1/R2 mice and also of $\mathrm{AD}$ patients is increased TEWL, ${ }^{16}$ which reflects the impaired inside-out barrier of the epidermis and results in severe skin dryness. Similar to the other epidermal

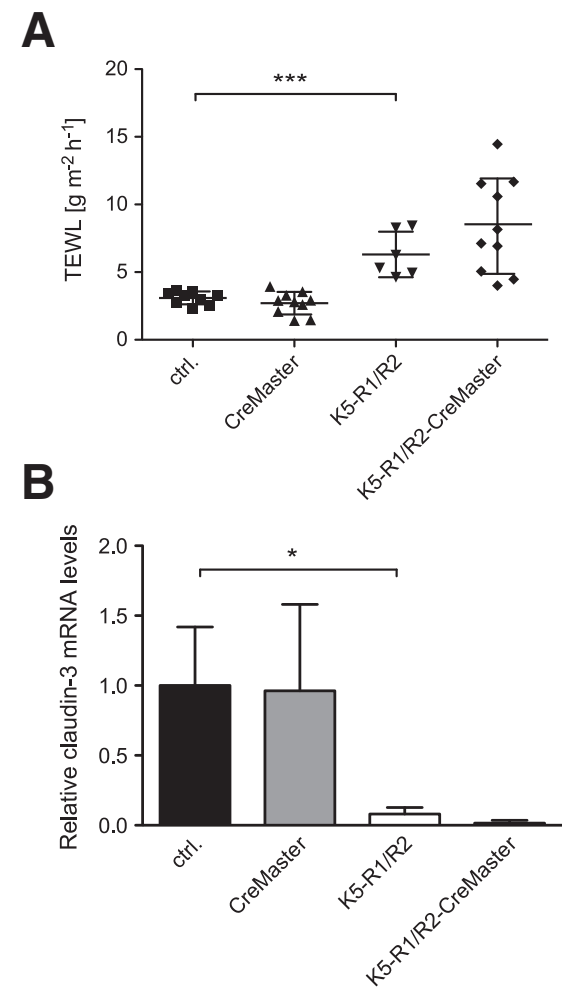

Figure 5 Loss of mast cells does not influence the epidermal barrier defect in K5-R1/R2 mice. A: Transepidermal water loss (TEWL) was measured on the back skin of 3-month-old control (ctrl) and K5-R1/R2 mice. B: RNA from the epidermis of 3-month-old mice was analyzed by quantitative real-time RT-PCR for the expression of claudin-3. Rps29 mRNA was used for normalization. Data are representative of two experiments and expressed as means \pm SD. $n=9$ control, 10 CreMaster, 6 K5-R1/R2, and $10 \mathrm{~K} 5-\mathrm{R} 1 / \mathrm{R} 2-$ CreMaster mice (A). $n=6$ control, 6 CreMaster, $3 \mathrm{~K} 5-\mathrm{R} 1 / \mathrm{R} 2$, and $3 \mathrm{~K} 5-\mathrm{R} 1 / \mathrm{R} 2-$ CreMaster mice $(\mathbf{B}) .{ }^{*} P \leq 0.05$, $* * * P \leq 0.001$. 
A
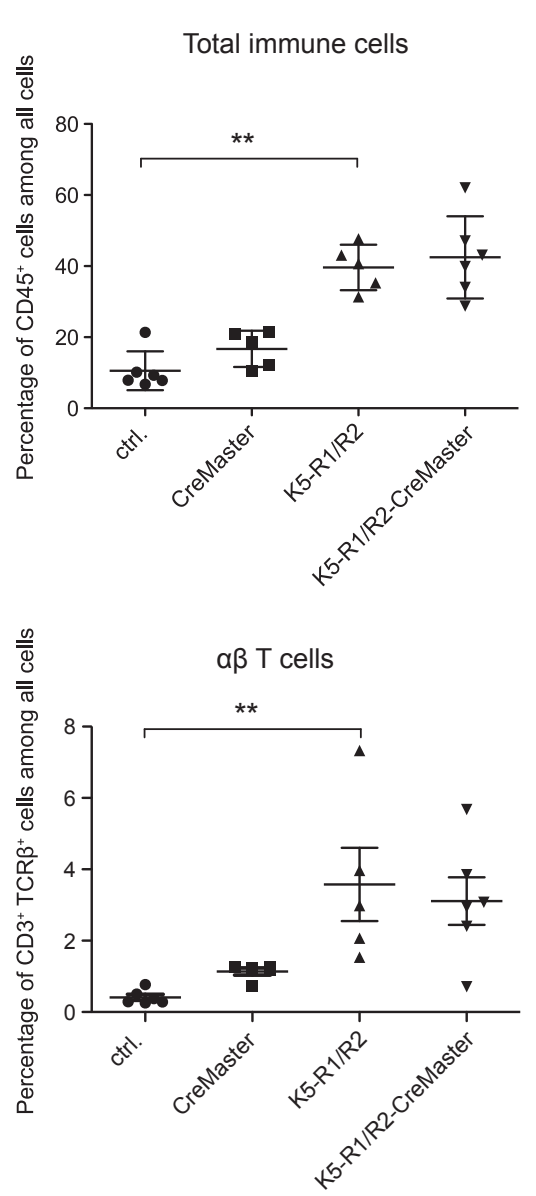

B

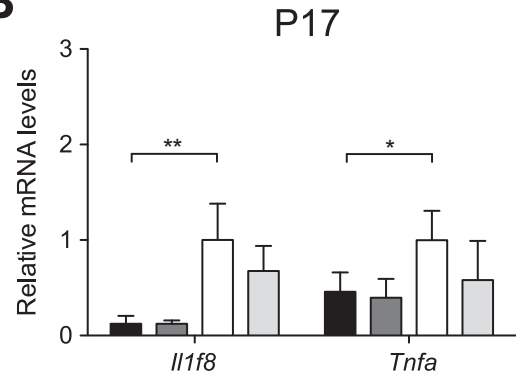

Epidermis
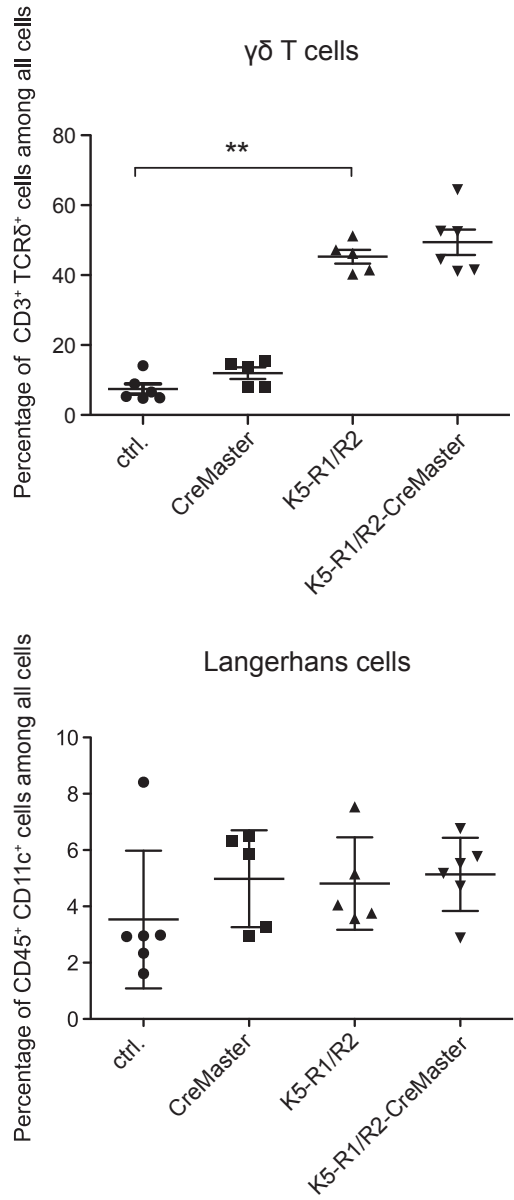

$3 \mathrm{M}$
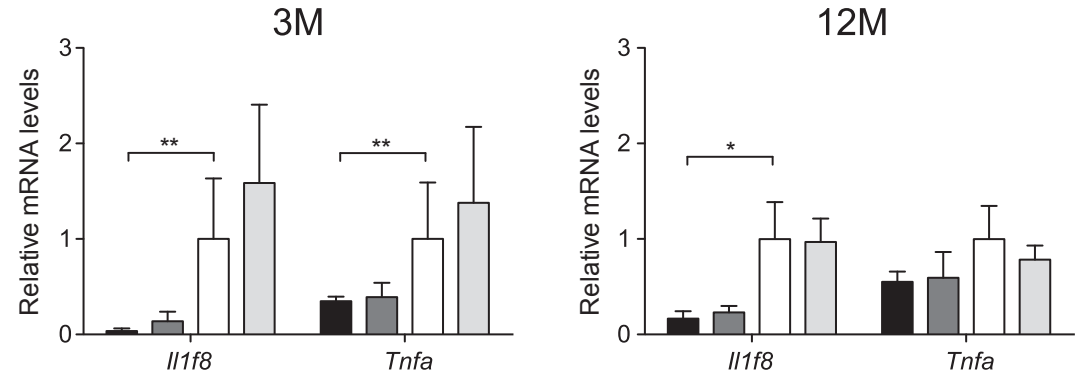

Figure 6 Loss of mast cells does not affect expression of proinflammatory cytokines or number of immune cells in the epidermis. A: Flow cytometry analysis of dissociated epidermal cells from 3-month-old (3M) mice for quantification of total $\mathrm{CD}_{4} 5^{+}$ immune cells, $\gamma \delta \mathrm{T}$ cells, $\alpha \beta \mathrm{T}$ cells, and Langerhans cells. B: RNA from the epidermis of postnatal day 17 (P17), 3-month-old, and 12-month-old (12M) mice was analyzed by quantitative real-time (RT-PCR) for the expression of Il-1f8 and tumor necrosis factor- $\alpha$. Rps29 mRNA was used for normalization. Data are representative of two experiments and indicate means \pm SD. $n=6$ control, 5 CreMaster, 5 K5-R1/R2, and 6 K5-R1/R2-CreMaster mice (A). $n=4$ control, 3 CreMaster, 6 K5-R1/R2, and 5 K5-R1/ R2-CreMaster mice for P17. $n=6$ control, 6 CreMaster, $6 \mathrm{~K} 5-\mathrm{R} 1 / \mathrm{R} 2$, and $6 \mathrm{~K} 5-\mathrm{R} 1 /$ R2-CreMaster mice for 3 months. $n=4$ control, 6 CreMaster, 4 K5-R1/R2, and 5 K5-R1/R2-CreMaster mice for 12 months (B). ${ }^{*} P \leq 0.05,{ }^{* *} P \leq 0.01$. abnormalities, the increase in TEWL that we observed in K5-R1/R2 compared with control mice was not affected by the lack of mast cells at the age of 3 months (Figure 5A) and 12 months (Supplemental Figure S4A).

We had previously found that the barrier function defect in $\mathrm{K} 5-\mathrm{R} 1 / \mathrm{R} 2$ mice is at least in part the result of reduced expression of major tight junction components, in particular of claudin-3. ${ }^{10}$ Consistent with the TEWL data, loss of mast cells did not influence the expression of Cldn 3 in the epidermis at the age of 3 months (Figure 5B) and 12 months (Supplemental Figure S4B). This finding further suggests that the impaired barrier function in K5-R1/R2 mice is a direct consequence of the deficiency in Fgfr signaling in keratinocytes rather than a secondary effect that results from the increase in mast cells.

\section{Loss of Mast Cells Does Not Affect the Extent of Cutaneous Inflammation in K5-R1/R2 Mice}

The defect in the epidermal barrier of AD patients is generally associated with cutaneous inflammation, characterized by an increase in various dermal and epidermal immune cells (Table 1). Because similar alterations had previously been observed in K5-R1/R2 mice, ${ }^{10}$ we assessed the contribution 

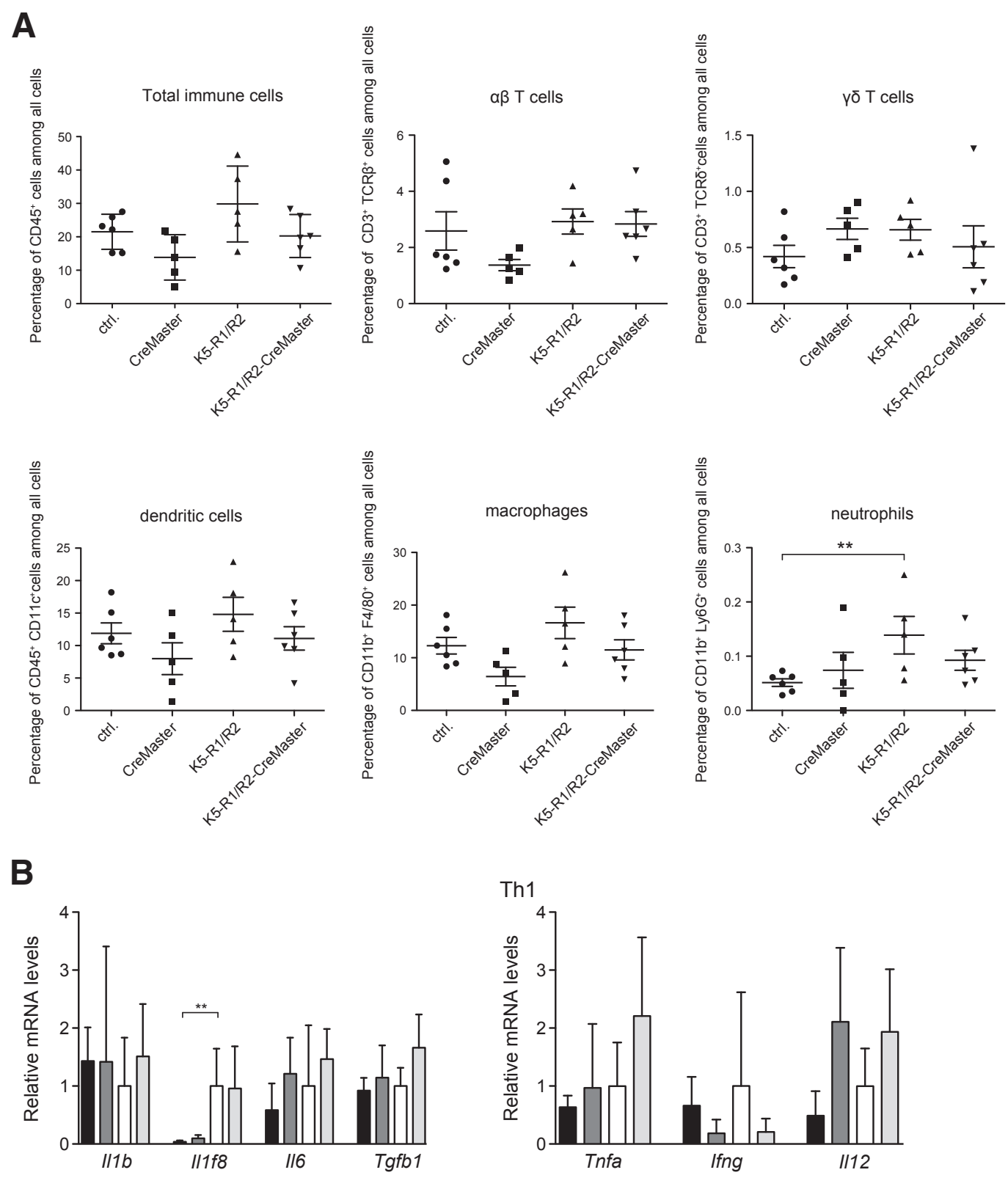

Th2

Thtr
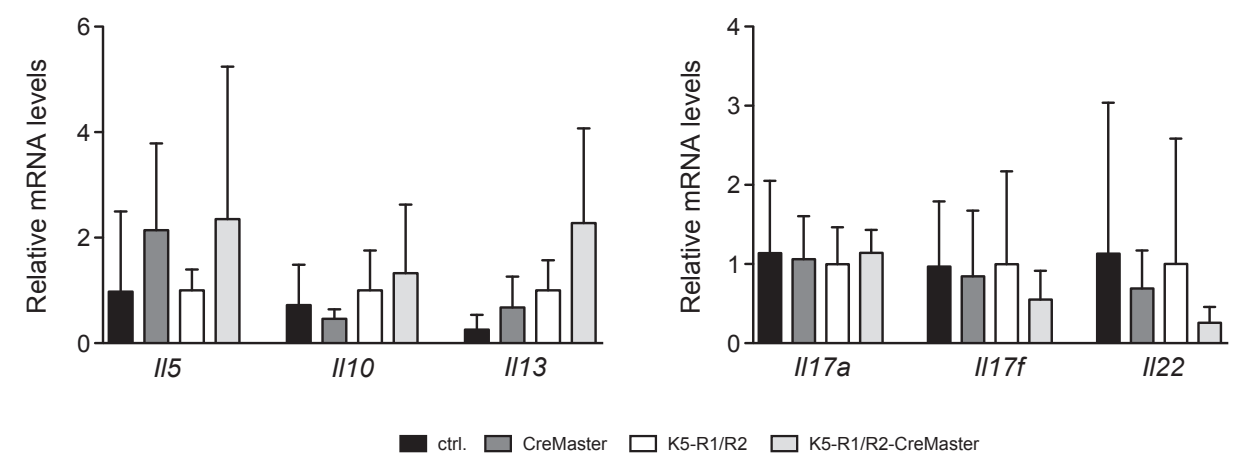

Figure 7 Loss of mast cells does not affect expression of proinflammatory cytokines or number of immune cells in the dermis. A: Flow cytometry analysis of dissociated dermal cells from 3-month-old mice for quantification of total CD45 immune cells, $\alpha \beta \mathrm{T}$ cells, $\gamma \delta \mathrm{T}$ cells, dendritic cells, macrophages, and neutrophils. B: RNA from the dermis of 3-month-old mice was analyzed by quantitative real-time RT-PCR for the expression of different cytokines. Rps29 mRNA was used for normalization. Data are representative of two experiments and expressed as means \pm SD. $n=6$ control, 5 CreMaster, 5 K5-R1/R2, and 6 K5-R1/ R2-CreMaster mice (A). $n=6$ control, 6 CreMaster, 6 K5-R1/R2, and 6 K5-R1/R2-CreMaster mice (B). ${ }^{* *} P \leq 0.01$. 
of mast cells to this inflammatory phenotype using flow cytometry analysis of different immune cells and RT-qPCR for various cytokines. A comparison of K5-R1/R2 and K5$\mathrm{R} 1 / \mathrm{R} 2$-CreMaster mice revealed no difference in the immune cell composition in the epidermis (Langerhans cells, $\alpha \beta \mathrm{T}$ cells, and $\gamma \delta \mathrm{T}$ cells) (Figure 6A) or in immune cell activation as determined by the analysis of CD69, CD86, and major histocompatibility complex II by flow cytometry (data not shown). Furthermore, epidermal expression levels of Il-1f8, a cytokine that is strongly up-regulated in the epidermis of K5-R1/R2 mice ${ }^{10}$ (Figure 6B) and of tumor necrosis factor- $\alpha$ was not affected by the loss of mast cells in mice of different age (Figure 6B). In the dermis, we detected a slight but nonsignificant decrease in the number of total immune cells, $\gamma \delta \mathrm{T}$ cells, dendritic cells, macrophages, and neutrophils in K5-R1/R2-CreMaster mice compared with K5-R1/R2 mice (Figure 7A). Some of these immune cells were also slightly but nonsignificantly reduced in CreMaster mice compared with wild-type controls. The cytokine expression profile, which included the major dermal $\mathrm{T}$ cell cytokines, was comparable between K5-R1/R2 and K5-R1/ R2-CreMaster mice at the age of 3 months (Figure 7B) and 12 months (Supplemental Figure S5). Therefore, mast cells do not or only slightly influence the inflammation in $\mathrm{K} 5-\mathrm{R} 1 / \mathrm{R} 2$ mice.

\section{Discussion}

Because of its exposure to the environment, the skin's integrity is essential for the prevention of acute and chronic inflammation as a result of invasion of irritants, allergens, or pathogens. Furthermore, the epidermal barrier protects from severe water loss.

Interestingly, most patients with $\mathrm{AD}$ have a genetic defect that affects key components of the epidermal barrier: the cornified envelope of the epidermis or the underlying tight junctions. $^{2-9}$ These mutations cause a disruption of the epidermal barrier, resulting in dry skin and diminished epidermal defense mechanisms to allergens and pathogens, followed by chronic inflammation. However, the contribution of different types of immune cells to the phenotypic abnormalities is not fully understood. We found that an increase in the number of mast cells and their rapid degranulation are some of the earliest events in the development of chronic skin inflammation in mice lacking Fgfr1 and Fgfr2 in keratinocytes.

As previously described, an increase in mast cells in the skin at the site of inflammation can result from a combination of local expansion of resident mast cells and attraction of bone marrow-derived MCPs, which subsequently proliferate in the skin. ${ }^{50}$ Interestingly, we also found an increase in the MCPs in the subcutaneous white adipose tissue of K5-R1/R2 mice at P9. Because white adipose tissue serves as a source of hematopoietic stem/progenitor cells, ${ }^{52,53}$ including MCPs, ${ }^{51}$ this increase may further contribute to the increase in skin mast cells.
Independent of the origin of the MCPs in K5-R1/R2 mice, the strong up-regulation of $\mathrm{Ccl} 2$, a major mast cell progenitor attractant, ${ }^{47}$ in the dermis and epidermis of K5-R1/R2 mice provides an explanation for the increased number of cutaneous mast cells. Furthermore, it may contribute to increased degranulation because in vitro treatment of mast cells with $\mathrm{Ccl} 2$ induced their degranulation. ${ }^{54}$

The reason for the up-regulation of $\mathrm{Ccl} 6$ and its target $\mathrm{Ccl} 2$ is as yet unknown. It is obviously not a direct consequence of the Fgfr deficiency because its expression was not upregulated in cultured keratinocytes of K5-R1/R2 mice and the increase also occurred in the dermis. Therefore, indirect effects, such as skin dryness that results in mechanical stress or alterations in the skin microbiome on development of the barrier defect, may contribute to their increased expression. The overexpression of $\mathrm{Ccl} 2$ and $\mathrm{Ccl} 6$ was only transient, possibly because of the onset of yet unknown compensatory mechanisms. This decrease may also explain why the number of mast cells did not further increase in the skin of K5-R1/R2 mice but rather decreased during aging, although the barrier function deficit persisted or was even aggravated. ${ }^{10}$ Because mast cells are able to survive for months or years, ${ }^{35}$ the mast cells present in aged mice may have been attracted to the skin during early postnatal development in response to the transient up-regulation of mast cell chemokines. The subsequent decrease in Ccl2 levels may also explain why fewer mast cells were degranulated in aged K5-R1/R2 mice.

Because patients with $\mathrm{AD}$ have increased numbers of mast cells in the skin, ${ }^{33,34}$ several studies used mouse models to address the role of mast cells in AD. Interestingly, there are apparent differences in the mast cell requirement among different $\mathrm{AD}$ models; hence, these models might mimic different aspects of the AD phenotype. However, the role of mast cells in the chronic dermatitis that develops in response to a genetic defect in the epidermal barrier had not yet been addressed. Although a mouse model can never fully mimic the human situation, K5-R1/R2 mice exhibit several important features of $\mathrm{AD}$ (Table 1) and are therefore suitable to address this question. Importantly, the increase in mast cells and their activation preceded the increase in other immune cells and the development of chronic cutaneous inflammation in these animals. Surprisingly, however, loss of mast cells in a K5-R1/R2 background due to Cremediated constitutive eradication of these cells did not affect any of the studied pathological features. However, we cannot exclude the possibility that they contribute to the response of the skin to an additional challenge, such as treatment with irritants and allergens or exposure to various pathogens. Further investigations along these lines will, however, remain challenging because the infertility of the mutant mice requires the use of heterozygous animals for breeding and only very limited numbers of quadruple mutant mice can be obtained. Furthermore, their rather poor health status did not allow the exposure to additional challenges. Other mouse models with impaired barrier may be useful to address this important question. Nevertheless, our 
genetic experiments strongly suggest that mast cells are dispensable for the development of the chronic skin inflammation in K5-R1/R2 mice and also are not major regulators of other immune cells in the inflamed skin.

\section{Acknowledgments}

We thank Dr. Anna-Katharina Müller (ETH Zurich) for invaluable experimental help, Katharina Blatter for excellent technical assistance, Dr. David Ornitz (Washington University, St Louis, MO) for kindly providing conditional Fgfrl/Fgfr2 knockout mice, and Dr. Manfred Kopf (ETH Zurich) for helpful suggestions.

\section{Supplemental Data}

Supplemental material for this article can be found at http://dx.doi.org/10.1016/j.ajpath.2015.02.005.

\section{References}

1. DaVeiga SP: Epidemiology of atopic dermatitis: a review. Allergy Asthma Proc 2012, 33:227-234

2. Brown SJ, McLean WH: Eczema genetics: current state of knowledge and future goals. J Invest Dermatol 2009, 129:543-552

3. Nomura T, Sandilands A, Akiyama M, Liao H, Evans AT, Sakai K, Ota M, Sugiura H, Yamamoto K, Sato H, Palmer CN, Smith FJ, McLean WH, Shimizu H: Unique mutations in the filaggrin gene in Japanese patients with ichthyosis vulgaris and atopic dermatitis. J Allergy Clin Immunol 2007, 119:434-440

4. Palmer CN, Irvine AD, Terron-Kwiatkowski A, Zhao Y, Liao H, Lee SP, Goudie DR, Sandilands A, Campbell LE, Smith FJ, O'Regan GM, Watson RM, Cecil JE, Bale SJ, Compton JG, DiGiovanna JJ, Fleckman P, Lewis-Jones S, Arseculeratne G, Sergeant A, Munro CS, El Houate B, McElreavey K, Halkjaer LB, Bisgaard H, Mukhopadhyay S, McLean WH: Common loss-offunction variants of the epidermal barrier protein filaggrin are a major predisposing factor for atopic dermatitis. Nat Genet 2006, 38:441-446

5. Sandilands A, Terron-Kwiatkowski A, Hull PR, O'Regan GM, Clayton TH, Watson RM, Carrick T, Evans AT, Liao H, Zhao Y, Campbell LE, Schmuth M, Gruber R, Janecke AR, Elias PM, van Steensel MA, Nagtzaam I, van Geel M, Steijlen PM, Munro CS, Bradley DG, Palmer CN, Smith FJ, McLean WH, Irvine AD: Comprehensive analysis of the gene encoding filaggrin uncovers prevalent and rare mutations in ichthyosis vulgaris and atopic eczema. Nat Genet 2007, 39:650-654

6. Kato A, Fukai K, Oiso N, Hosomi N, Murakami T, Ishii M: Association of SPINK5 gene polymorphisms with atopic dermatitis in the Japanese population. Br J Dermatol 2003, 148:665-669

7. Nishio Y, Noguchi E, Shibasaki M, Kamioka M, Ichikawa E, Ichikawa K, Umebayashi Y, Otsuka F, Arinami T: Association between polymorphisms in the SPINK5 gene and atopic dermatitis in the Japanese. Genes Immun 2003, 4:515-517

8. Walley AJ, Chavanas S, Moffatt MF, Esnouf RM, Ubhi B, Lawrence R, Wong $\mathrm{K}$, Abecasis GR, Jones EY, Harper JI, Hovnanian A, Cookson WO: Gene polymorphism in Netherton and common atopic disease. Nat Genet 2001, 29:175-178

9. De Benedetto A, Rafaels NM, McGirt LY, Ivanov AI, Georas SN, Cheadle C, Berger AE, Zhang K, Vidyasagar S, Yoshida T, Boguniewicz M, Hata T, Schneider LC, Hanifin JM, Gallo RL, Novak N, Weidinger S, Beaty TH, Leung DY, Barnes KC, Beck LA:
Tight junction defects in patients with atopic dermatitis. J Allergy Clin Immunol 2011, 127:773-786.e1-7

10. Yang J, Meyer M, Muller AK, Bohm F, Grose R, Dauwalder T, Verrey F, Kopf M, Partanen J, Bloch W, Ornitz DM, Werner S: Fibroblast growth factor receptors 1 and 2 in keratinocytes control the epidermal barrier and cutaneous homeostasis. J Cell Biol 2010, 188:935-952

11. Fallon PG, Sasaki T, Sandilands A, Campbell LE, Saunders SP, Mangan NE, Callanan JJ, Kawasaki H, Shiohama A, Kubo A, Sundberg JP, Presland RB, Fleckman P, Shimizu N, Kudoh J, Irvine $\mathrm{AD}$, Amagai $\mathrm{M}$, McLean $\mathrm{WH}$ : A homozygous frameshift mutation in the mouse Flg gene facilitates enhanced percutaneous allergen priming. Nat Genet 2009, 41:602-608

12. Saunders SP, Goh CS, Brown SJ, Palmer CN, Porter RM, Cole C, Campbell LE, Gierlinski M, Barton GJ, Schneider G, Balmain A, Prescott AR, Weidinger S, Baurecht H, Kabesch M, Gieger C, Lee YA, Tavendale R, Mukhopadhyay S, Turner SW, Madhok VB, Sullivan FM, Relton C, Burn J, Meggitt S, Smith CH, Allen MA, Barker JN, Reynolds NJ, Cordell HJ, Irvine AD, McLean WH, Sandilands A, Fallon PG: Tmem79/Matt is the matted mouse gene and is a predisposing gene for atopic dermatitis in human subjects. $\mathrm{J}$ Allergy Clin Immunol 2013, 132:1121-1129

13. Scharschmidt TC, Man MQ, Hatano Y, Crumrine D, Gunathilake R, Sundberg JP, Silva KA, Mauro TM, Hupe M, Cho S, Wu Y, Celli A, Schmuth M, Feingold KR, Elias PM: Filaggrin deficiency confers a paracellular barrier abnormality that reduces inflammatory thresholds to irritants and haptens. J Allergy Clin Immunol 2009, 124:496-506, 506.e1-6

14. Guttman-Yassky E, Suarez-Farinas M, Chiricozzi A, Nograles KE, Shemer A, Fuentes-Duculan J, Cardinale I, Lin P, Bergman R, Bowcock AM, Krueger JG: Broad defects in epidermal cornification in atopic dermatitis identified through genomic analysis. J Allergy Clin Immunol 2009, 124:1235-1244.e58

15. Park HK, Park HW, Jeon SG, Shin ES, Gho YS, Cho SH, Kim YY, Kim YK: Distinct association of genetic variations of vascular endothelial growth factor, transforming growth factor-beta, and fibroblast growth factor receptors with atopy and airway hyperresponsiveness. Allergy 2008, 63:447-453

16. Sugarman JL, Fluhr JW, Fowler AJ, Bruckner T, Diepgen TL, Williams ML: The objective severity assessment of atopic dermatitis score: an objective measure using permeability barrier function and stratum corneum hydration with computer-assisted estimates for extent of disease. Arch Dermatol 2003, 139:1417-1422

17. Moniaga CS, Egawa G, Kawasaki H, Hara-Chikuma M, Honda T, Tanizaki H, Nakajima S, Otsuka A, Matsuoka H, Kubo A, Sakabe J, Tokura Y, Miyachi Y, Amagai M, Kabashima K: Flaky tail mouse denotes human atopic dermatitis in the steady state and by topical application with Dermatophagoides pteronyssinus extract. Am J Pathol 2010, 176:2385-2393

18. Kiehl P, Falkenberg K, Vogelbruch M, Kapp A: Tissue eosinophilia in acute and chronic atopic dermatitis: a morphometric approach using quantitative image analysis of immunostaining. Br J Dermatol 2001, 145:720-729

19. Dumortier A, Durham AD, Di Piazza M, Vauclair S, Koch U, Ferrand G, Ferrero I, Demehri S, Song LL, Farr AG, Leonard WJ, Kopan R, Miele L, Hohl D, Finke D, Radtke F: Atopic dermatitislike disease and associated lethal myeloproliferative disorder arise from loss of Notch signaling in the murine skin. PLoS One 2010, 5:e9258

20. Yang GY, Chen X, Sun YC, Ma CL, Qian G: Chemokine-like factor 1 (CLFK1) is over-expressed in patients with atopic dermatitis. Int J Biol Sci 2013, 9:759-765

21. Presland RB, Boggess D, Lewis SP, Hull C, Fleckman P, Sundberg JP: Loss of normal profilaggrin and filaggrin in flaky tail (ft/ft) mice: an animal model for the filaggrin-deficient skin disease ichthyosis vulgaris. J Invest Dermatol 2000, 115:1072-1081

22. Oyoshi MK, Murphy GF, Geha RS: Filaggrin-deficient mice exhibit TH17-dominated skin inflammation and permissiveness to 
epicutaneous sensitization with protein antigen. J Allergy Clin Immunol 2009, 124:485-493, 493.e1

23. Leisten S, Oyoshi MK, Galand C, Hornick JL, Gurish MF, Geha RS: Development of skin lesions in filaggrin-deficient mice is dependent on adaptive immunity. J Allergy Clin Immunol 2013, 131:1247-1250, 1250.e1

24. Ott NL, Gleich GJ, Peterson EA, Fujisawa T, Sur S, Leiferman KM: Assessment of eosinophil and neutrophil participation in atopic dermatitis: comparison with the IgE-mediated late-phase reaction. J Allergy Clin Immunol 1994, 94:120-128

25. Yamashita N, Kaneko S, Kouro O, Furue M, Yamamoto S, Sakane T: Soluble E-selectin as a marker of disease activity in atopic dermatitis. J Allergy Clin Immunol 1997, 99:410-416

26. Chorro L, Sarde A, Li M, Woollard KJ, Chambon P, Malissen B, Kissenpfennig A, Barbaroux JB, Groves R, Geissmann F: Langerhans cell (LC) proliferation mediates neonatal development, homeostasis, and inflammation-associated expansion of the epidermal LC network. J Exp Med 2009, 206:3089-3100

27. Kypriotou M, Boechat C, Huber M, Hohl D: Spontaneous atopic dermatitis-like symptoms in a/a ma ft/ma ft/J flaky tail mice appear early after birth. PLoS One 2013, 8:e67869

28. Schafer L, Kragballe K, Jepsen LV, Iversen L: Reduced neutrophil LTB4 release in atopic dermatitis patients despite normal fatty acid composition. J Invest Dermatol 1991, 96:16-19

29. Choy DF, Hsu DK, Seshasayee D, Fung MA, Modrusan Z, Martin F, Liu FT, Arron JR: Comparative transcriptomic analyses of atopic dermatitis and psoriasis reveal shared neutrophilic inflammation. J Allergy Clin Immunol 2012, 130:1335-1343.e5

30. Dhingra N, Suarez-Farinas M, Fuentes-Duculan J, Gittler JK, Shemer A, Raz A, Fischetti VA, Krueger JG, Guttman-Yassky E: Attenuated neutrophil axis in atopic dermatitis compared to psoriasis reflects TH17 pathway differences between these diseases. J Allergy Clin Immunol 2013, 132:498-501.e3

31. Werfel T, Morita A, Grewe M, Renz H, Wahn U, Krutmann J, Kapp A: Allergen specificity of skin-infiltrating $\mathrm{T}$ cells is not restricted to a type-2 cytokine pattern in chronic skin lesions of atopic dermatitis. J Invest Dermatol 1996, 107:871-876

32. Hijnen D, Knol EF, Gent YY, Giovannone B, Beijn SJ, Kupper TS, Bruijnzeel-Koomen CA, Clark RA: CD8(+) T cells in the lesional skin of atopic dermatitis and psoriasis patients are an important source of IFNgamma, IL-13, IL-17, and IL-22. J Invest Dermatol 2013, 133:973-979

33. Damsgaard TE, Olesen AB, Sorensen FB, Thestrup-Pedersen K, Schiotz PO: Mast cells and atopic dermatitis. Stereological quantification of mast cells in atopic dermatitis and normal human skin. Arch Dermatol Res 1997, 289:256-260

34. Kawakami T, Ando T, Kimura M, Wilson BS, Kawakami Y: Mast cells in atopic dermatitis. Curr Opin Immunol 2009, 21:666-678

35. Abraham SN, Malaviya R: Mast cells in infection and immunity. Infect Immun 1997, 65:3501-3508

36. Abraham SN: St John AL: mast cell-orchestrated immunity to pathogens. Nat Rev Immunol 2010, 10:440-452

37. Alenius H, Laouini D, Woodward A, Mizoguchi E, Bhan AK, Castigli E, Oettgen HC, Geha RS: Mast cells regulate IFN-gamma expression in the skin and circulating IgE levels in allergen-induced skin inflammation. J Allergy Clin Immunol 2002, 109:106-113

38. Abboud G, Staumont-Salle D, Kanda A, Roumier T, Deruytter N, Lavogiez C, Fleury S, Remy P, Papin JP, Capron M, Dombrowicz D: $\mathrm{Fc}($ epsilon)RI and FcgammaRIII/CD16 differentially regulate atopic dermatitis in mice. J Immunol 2009, 182:6517-6526

39. Oiwa M, Satoh T, Watanabe M, Niwa H, Hirai H, Nakamura M, Yokozeki H: CRTH2-dependent, STAT6-independent induction of cedar pollen dermatitis. Clin Exp Allergy 2008, 38:1357-1366
40. Ando T, Xiao W, Gao P, Namiranian S, Matsumoto K, Tomimori Y, Hong H, Yamashita H, Kimura M, Kashiwakura J, Hata TR, Izuhara K, Gurish MF, Roers A, Rafaels NM, Barnes KC, Jamora C, Kawakami Y, Kawakami T: Critical role for mast cell Stat5 activity in skin inflammation. Cell Rep 2014, 6:366-376

41. Ando T, Matsumoto K, Namiranian S, Yamashita H, Glatthorn H, Kimura M, Dolan BR, Lee JJ, Galli SJ, Kawakami Y, Jamora C, Kawakami T: Mast cells are required for full expression of allergen/SEB-induced skin inflammation. J Invest Dermatol 2013, 133:2695-2705

42. Lilla JN, Chen CC, Mukai K, BenBarak MJ, Franco CB, Kalesnikoff J, Yu M, Tsai M, Piliponsky AM, Galli SJ: Reduced mast cell and basophil numbers and function in Cpa3-Cre; Mcl-1fl/fl mice. Blood 2011, 118:6930-6938

43. Grimbaldeston MA, Chen CC, Piliponsky AM, Tsai M, Tam SY, Galli SJ: Mast cell-deficient W-sash c-kit mutant Kit W-sh/W-sh mice as a model for investigating mast cell biology in vivo. Am J Pathol 2005, 167:835-848

44. Nocka K, Tan JC, Chiu E, Chu TY, Ray P, Traktman P, Besmer P: Molecular bases of dominant negative and loss of function mutations at the murine c-kit/white spotting locus: W37, Wv, W41 and W. Embo J 1990, 9:1805-1813

45. Feyerabend TB, Weiser A, Tietz A, Stassen M, Harris N, Kopf M, Radermacher P, Moller P, Benoist C, Mathis D, Fehling HJ, Rodewald HR: Cre-mediated cell ablation contests mast cell contribution in models of antibody- and $\mathrm{T}$ cell-mediated autoimmunity. Immunity 2011, 35:832-844

46. Werner S, Smola H, Liao X, Longaker MT, Krieg T, Hofschneider PH, Williams LT: The function of KGF in morphogenesis of epithelium and reepithelialization of wounds. Science 1994, 266:819-822

47. Collington SJ, Hallgren J, Pease JE, Jones TG, Rollins BJ, Westwick J, Austen KF, Williams TJ, Gurish MF, Weller CL: The role of the CCL2/CCR2 axis in mouse mast cell migration in vitro and in vivo. J Immunol 2010, 184:6114-6123

48. Coelho AL, Schaller MA, Benjamim CF, Orlofsky AZ, Hogaboam CM, Kunkel SL: The chemokine CCL6 promotes innate immunity via immune cell activation and recruitment. J Immunol 2007, 179:5474-5482

49. Kanbe T, Soma Y, Kawa Y, Kashima M, Mizoguchi M: Serum levels of soluble stem cell factor and soluble KIT are elevated in patients with atopic dermatitis and correlate with the disease severity. Br J Dermatol 2001, 144:1148-1153

50. Hatanaka K, Kitamura Y, Nishimune Y: Local development of mast cells from bone marrow-derived precursors in the skin of mice. Blood 1979, 53:142-147

51. Poglio S, De Toni-Costes F, Arnaud E, Laharrague P, Espinosa E, Casteilla L, Cousin B: Adipose tissue as a dedicated reservoir of functional mast cell progenitors. Stem Cells 2010, 28:2065-2072

52. Blogowski W, Ratajczak MZ, Zyzniewska-Banaszak E, Dolegowska B, Starzynska T: Adipose tissue as a potential source of hematopoietic stem/progenitor cells. Obesity (Silver Spring) 2012, 20: 923-931

53. Cousin B, Andre M, Arnaud E, Penicaud L, Casteilla L: Reconstitution of lethally irradiated mice by cells isolated from adipose tissue. Biochem Biophys Res Commun 2003, 301:1016-1022

54. Conti P, Boucher W, Letourneau R, Feliciani C, Reale M, Barbacane RC, Vlagopoulos P, Bruneau G, Thibault J, Theoharides TC: Monocyte chemotactic protein-1 provokes mast cell aggregation and [3H]5HT release. Immunology 1995, 86:434-440

55. Chen CC, Grimbaldeston MA, Tsai M, Weissman IL, Galli SJ: Identification of mast cell progenitors in adult mice. Proc Natl Acad Sci U S A 2005, 102:11408-11413 